\title{
Foliar growth of Eriocnema fulva Naudin (Melastomataceae) in a forest fragment in southeastern Brazil
}

\author{
Andrade, PM. ${ }^{\mathrm{a}}$, Santos, FAM. ${ }^{\mathrm{b}}$, and Martins, FR. ${ }^{\mathrm{b}, *}$ \\ anstituto Estadual de Florestas, Rua Espírito Santo 495, CEP 30160-030, Belo Horizonte, MG, Brazil \\ bDepartamento de Botânica, Instituto de Biologia, Universidade Estadual de Campinas - UNICAMP, \\ CP 6109, CEP 13083-970, Campinas, SP, Brazil \\ *e-mail: fmartins@unicamp.br
}

Received September 20, 2005 - Accepted August 21, 2006 - Distributed February 29, 2008

(With 3 figures)

\begin{abstract}
Eriocnema fulva Naudin is an endangered herbaceous, perennial, iteroparous, evergreen species geographically restricted to southeastern-center Minas Gerais State, SE Brazil. The individuals occur as patches on rocky riverbanks shaded by seasonal semideciduous Atlantic forest; they are fixed by roots and have a pending stem. Aiming to investigate leaf development and its importance for individual survival, fifteen contiguous plots $(1 \times 1 \mathrm{~m})$ were set down in Jambreiro Forest $\left(19^{\circ} 58^{\prime}-59^{\prime} \mathrm{S}\right.$ and $43^{\circ} 52^{\prime}-55^{\prime} \mathrm{W}, 800-1100 \mathrm{~m}$ altitude), in the municipality of Nova Lima. A total of 260 individuals with the largest leaf blade length $\geq 1 \mathrm{~cm}$ was tagged and measured in 1997, 1998, and 1999. Leaf expansion was recorded each month during 26 months until April 2000. Plant size was measured through leaf blade length, petiole length, stem length, and number of leaves. Significant changes were detected only after two years, thus indicating that plant growth is slow. The proportion of surviving leaves after two years was $60 \%$. Total blade expansion took over 14 months, a slow growth rate when compared to leaves of other tropical forest canopy and understory species. Long leaf lifespans are to be found in plants exhibiting slow growth, and we observed that some leaves lived longer than three years. Petiole growth can help to better position the leaf in the search for light, thus contributing to the growth and survival of the plant. The relationships among size measures were significant, reinforcing the great contribution of leaf size for plant size. The age of the largest individual was estimated as 36 years based on the median annual leaf production rate.
\end{abstract}

Keywords: leaf growth, leaf lifespan, herbaceous plant, size, age.

\section{Crescimento foliar de Eriocnema fulva Naudin (Melastomataceae) em um fragmento florestal no Brasil sudeste}

\begin{abstract}
Resumo
Eriocnema fulva é uma espécie herbácea, perene, iteropárica, com distribuição geográfica restrita ao centro-sudeste do Estado de Minas Gerais, Brasil, e ameaçada de extinção. Os indivíduos ocorrem agrupados em paredões rochosos, na beira de riachos sombreados pela Mata Atlântica estacional semidecídua e têm caule que pendem do barranco. Com o objetivo de investigar o desenvolvimento da folha e sua importância para a sobrevivência dos indivíduos, foram instaladas 15 parcelas contíguas de 1 x 1 m na Mata do Jambreiro (19 ${ }^{\circ}$ 58'-59' S, 43 52'-55' W, 800-1100 m de altitude), município de Nova Lima. Todos os indivíduos cuja maior folha tivesse comprimento do limbo maior ou igual a $1 \mathrm{~cm}$ foram marcados, sendo medidos em 1997, 1998 e 1999. O tempo de expansão da folha foi registrado mensalmente durante 26 meses até abril de 2000. Na área amostrada foram marcados 260 indivíduos cujo limbo foliar tinha comprimento $\geq 1 \mathrm{~cm}$. O tamanho das plantas, medido através do comprimento do limbo e do pecíolo e do número de folhas, apresentou mudanças significativas somente após dois anos, indicando que o crescimento é lento. A proporção das folhas sobreviventes após dois anos foi de 60\%. O tempo necessário para a expansão da folha foi superior a 14 meses e é lento quando comparado com o de outras espécies do dossel ou do sub-bosque da floresta tropical. Maior longevidade foliar tende a ser encontrada em plantas de crescimento lento. Observamos que algumas folhas tiveram maior longevidade que 3 anos. O crescimento do pecíolo pode ajudar no melhor posicionamento da folha na busca de luz no sub-bosque, contribuindo para o crescimento e sobrevivência da planta. As relações entre a folha e demais medidas de tamanho foram significativas, indicando sua grande importância para o tamanho de cada planta. A idade do indivíduo de maior tamanho foi estimada em 36 anos através da taxa mediana de produção anual de folhas.
\end{abstract}

Palavras-chave: crescimento foliar, longevidade foliar, planta herbácea, tamanho, idade. 


\section{Introduction}

Plant growth is in part determined by leaf dynamics and longevity (Givnish, 1984), because leaves are related to the plant carbon gain (Chabot and Hicks, 1982). The dynamics of leaves and their arrangement in space make plant architecture an important element in the plant strategy to sequester carbono. The relationships between longevity, size, and emergence pattern of leaves, in conjunction with plant architecture, affect primary productivity (Kikuzawa, 1995) and, consequently, plant survival. Leaf longevity varies from a few weeks in ephemeral plants to more than 10 years in some perennial species (Chabot and Hicks, 1982; Reich et al. 1992). Plant growth rates decline with increase in leaf lifespan, and the longer the leaf lives the slower the plant grows (Mulkey et al., 1991; Reich et al., 1992; Crawley, 1997). Leaf development is generally interpreted as part of the plant program of resource allocation and physiological aging, and leaf lifespan is part of a general adaptive strategy (Thomas and Stoddart, 1980; apud Chabot and Hicks, 1982).

Leaves are important for plants of all sizes, be they trees, shrubs, or herbs. There are many studies involving the ecology of leaves, some focusing on leaf longevity and carbon gain (Bentley, 1979; Chabot and Hicks, 1982; Harper, 1989; Mulkey et al., 1991; Reich et al., 1992; Coley et al., 1993; Mulkey et al., 1993; Walker and Aplet, 1994; Kikuzawa, 1995; Kitajima et al., 1997; Freiberg and Freiberg, 1999; Kursar and Coley, 1999), others dealing with leaf dynamics (Jurik and Chabot, 1986; Escudero and Del Arco, 1987; Costa and Seeliger, 1988a,b; Hegarty, 1990; Costa et al., 1991; Cavelier et al., 1992; Clark et al., 1992; Lowman, 1992; Aide, 1993; Telenius, 1993; Diemer, 1998; Carvalho et al., 1999; Santos, 2000; Williams-Linera, 2000), and still others accessing questions related to allometry and leaf size (Parkhurst and Louks, 1972; Richards, 1976; Dolph and Dilcher, 1980; Kohyama, 1987; Kohyama and Hotta, 1990; Sterk and Bonges, 1998; Becker et al., 1999; Valladares et al., 2002). Yet, in tropical forests, studies of leaf dynamics of herbaceous plants are few (Mulkey et al., 1991; Sharpe, 1993; Horvitz and Schemske, 1995; Bruna and Kress, 2002). Leaves are believed to be particularly important for the survival of an herbaceous plant when they are large in comparison to the plant total size. In such cases, in addition to shoots and stem, the leaves and the petioles contribute directly to the architecture of the plant. In tropical environments, leaves of understory plants tend to possess longer longevity and greater size than leaves in the canopy (Parkhurst and Loucks, 1972; Reich et al., 1991; 1992).

Eriocnema fulva is a perennial, iteroparous, herbaceous species with a prostrate stem, endemic to centralsoutheastern Minas Gerais state, SE Brazil. Up to the present, this species has been recorded only in the municipalities of Ouro Preto and Sabará (Cogniaux, 1883; Badini, 1940) and Nova Lima (Andrade, 1993). It occurs as groups of individuals on rocky riverbanks shaded by seasonal semideciduous Atlantic forest. E. fulva does not associate with other species of angiosperms, but only with mosses and ferns (personal observation). Recent studies showed that the reproductive system of this species is self-compatible; it does not produce fruits via either autogamy or agamospermy, but requires, obligatorily, pollen vectors due to buzz pollination syndrome (Andrade, 2004). The root system is individualized and vegetative reproduction was not observed. Although it is in the endangered species list (COPAM, 1997), there is little information regarding its biology, occurrence sites, abundance, or population structure (Andrade, 2004). This information is essential in order to develop conservation and management strategies.

Considering the small total size of Eriocnema fulva, we expect that leaf development characteristics are important for this species, which dwells in the inferior stratum of a tropical forest. We also expect that aspects related to leaf development and lifespan are relevant to individual survival. The objectives of this study are: 1) to describe aspects of leaf development of an herbaceous perennial species from the inferior stratum of a tropical semideciduous forest; and 2) to investigate the importance of the leaf and its alterations during ontogeny for the species survival. In order to reach these objectives we formulate the following questions as guidelines: 1) How does a leaf and its petiole grow? 2) Does the number of leaves increase during plant ontogenesis? 3) How long does a leaf last? 4) Does leaf size have any relation to leaf longevity? 5) Is leaf growth related to the structure of the plant and population? and 6) Is it possible to estimate individual age based on leaf characteristics?

\section{Material and Methods}

\subsection{Study area}

This study took place in the Jambreiro Forest (912 hectares), located in the central-southeastern region of Minas Gerais State, between $19^{\circ} 58^{\prime}-59^{\prime} \mathrm{S}$ and $43^{\circ} 52^{\prime}-55^{\prime} \mathrm{W}$, in the municipality of Nova Lima, metropolitan region of Belo Horizonte. The region of Nova Lima is located in the Quadrilátero Ferrífero, a region with iron ore sites (Alves, 1988). The climate is Koeppen's Cwa, macrothermic temperate with mild summers and dry winters. Rains (1400-1600 mm/year) predominate during the hottest period (October to March), the mean annual temperature is $18{ }^{\circ} \mathrm{C}$, mean maximum temperature is $21^{\circ} \mathrm{C}$, and the mean minimum temperature is $14^{\circ} \mathrm{C}$ (Alves, 1988). The soil is dystrophic Cambisol (CETEC, 1983), the altitudes vary between 800 and $1100 \mathrm{~m}$, and the relief has an undulating topography. This study was done in an area adjacent to the stream Ribeirão do Cardoso, at an altitude of $850 \mathrm{~m}$ (PLAMBEL, 1977). The terrain on which the Jambreiro Forest occurs belongs to the company Minerações Brasileiras Reunidas (MBR). In August 1998 it was protected as a private reserve (Reserva Particular do Patrimônio Natural - RPPN), a form of land conservation in Brazil, which began with 
a legal instrument (Portaria number 070, September 11, 1998) from the Instituto Estadual de Florestas (IEF), a state environmental agency in Minas Gerais.

\subsection{Data collection}

In the RPPN Jambreiro Forest, Eriocnema fulva occurs in patches on rocky, shaded riverbanks. In one of these patches 15 contiguous plots $(1 \times 1 \mathrm{~m})$ were established. These plots were delimited by cotton string tied to small nails attached to the rocky walls. All individuals with the largest leaf length greater than or equal to $1 \mathrm{~cm}$ were tagged by a numbered aluminum identifying tag. For each tagged individual the total number of leaves was recorded, and the petiole length and the length and width of the blade of the largest leaf were measured. Stem length was measured, except in small plants, in which the stem was so short that no measurement was possible. In these cases, we stated that the plant had a non-measurable stem, and we represented the non-measured stem length as a " 0 " category in our graphs. Tagged individuals were counted and measured for the first time in 1997 and again in 1998 and 1999, at intervals of 414 and 363 days, respectively. The subset of data collected in 1997 was used to classify individuals into size classes. We did not include plants with leaves smaller than $1 \mathrm{~cm}$ because their frailty and reduced size made impossible to perform the measurements. In order to search for temporal variations of the number of individuals, number of leaves, and size differences we used the measurements taken in 1997, 1998, and 1999. To investigate leaf expansion, we measured petiole and blade length of 35 leaves in 28 reproductive individuals, which were selected among the largest individuals in the population, in intervals of 27 to 35 days, during 26 monthly observations. We labeled leaves with lightweight numbered tags, and tied them to the plants with cotton string in order to not harm leaf development. We identified leaves in the initial process of expansion by their position on the tip of the stem, their reduced size and light-green coloration. Tracking and measuring leaves were done during the 26 monthly observations, even if no growth was measured. Measurements were performed by means of a graduated ruler and measuring tape.

\subsection{Data analysis}

We delimited size class intervals by means of dispersion diagrams combining leaf length, stem length, number of leaves, and number of fruits. Reproductive plants were recognized by the presence of reproductive structures, such as flowers and fruits; plants without these structures were considered vegetative. We divided plants into two categories: vegetative and reproductive. During measurements, a great difference was observed between small and large leaves, and we classified leaves into two classes of blade length: small (up to $7 \mathrm{~cm}$ ) and large (greater than $7 \mathrm{~cm}$ ).

We investigated the relationships among the leaf size measures in the population as a whole by means of linear regressions and also by using the model $\mathrm{y}=\mathrm{ax}^{\mathrm{b}}$, where $\mathrm{a}$ and $\mathrm{b}$ are constants, and the data were transformed into natural logarithm. (Zar, 1984). In order to test for size variation between the initial (1997) and the final (1999) observation, we performed regressions and performed tests for the differences between angular coefficients (b) and intercepts (a) with covariance analyses and a posteriori Scheffé test (Sokal and Rolf, 1969). ANCOVA and Sheffé tests were applied only on significant regressions by using the program ANCOVA developed by F. A. M. Santos. We analyzed the variation in the number of leaves between the initial (1997) and the final (1999) observations using the Kruskal-Wallis test (Zar, 1984). We estimated the median number of leaves produced per year based on the number of leaves of all individuals in the initial (1997) and the final (1999) observation, excluding the dead plants. The confidence interval for the median was calculated following Zar (1984).

For the analysis of monthly growth of leaf and petiole, we considered all data up to stationary growth, that is, until the measure had the same value in three consecutive months. As the measurements were done in intervals varying from 27 to 35 days, the final monthly growth rate of leaf and petiole was expressed on a 30-day base. The difference of growth rate between small and large leaves was tested by Mann-Whitney U test including Z (value of the deviation from normal distribution) because the sample contained more than 20 individuals (Zar, 1984). The Mann-Whitney test was also used to test for differences in petiole growth rate. In order to estimate plant age based on the increase of the number of leaves a correlation using Pearson coefficient was done considering the number of leaves in the population between 1997 and 1999 (Zar, 1984). By applying the equation $\mathrm{NL}_{\mathrm{t}}=\mathrm{a}+\mathrm{b} \cdot \mathrm{NL}_{\mathrm{t}-2}$, where $\mathrm{NL}=$ number of leaves, $\mathrm{a}$ and $\mathrm{b}=$ constants, $\mathrm{t}=$ time in years, constants were generated. Based on these constants we made a projection of the increase in the number of leaves over time, which generated a non-linear model. This projection was done only until the number of leaves in the projection was similar to that of the largest plant found in the population.

\section{Results}

\subsection{Leaf growth and survival}

Leaf display on individuals changed with plant size. Large individuals, be they reproductive or not, bare the smallest leaves close to the stem, due to their short petioles, on the upward part of the plant; while the largest leaves, with longer petioles, are situated on the part of the plant facing downward (Figure 1). Leaf display in small individuals (" 0 " stem length) formed a rosette, because the stem is very short. When starting expansion, the leaf was more flexible and had light-green color; mature leaves had a firmer and more resistant consistency and dark-green color, although they could continue to grow for long time. The flux of leaves was continuous, one leaf emerging at a time. That is, there were not several new leaves present at the same time, but since we 
(a)
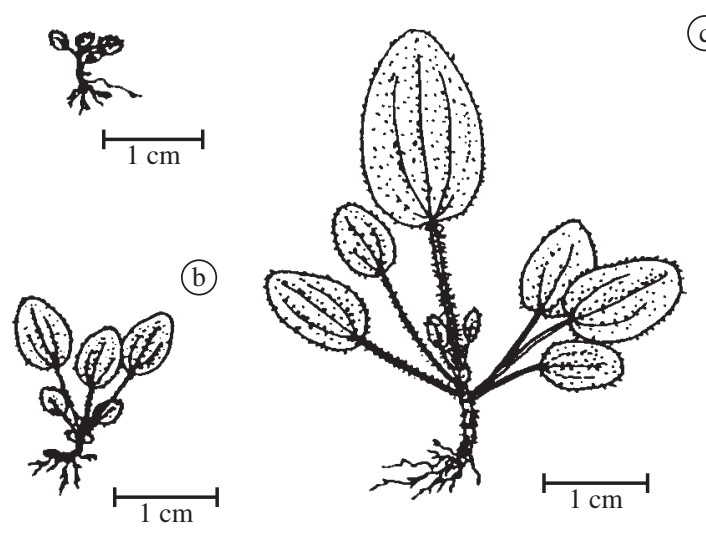

(c)

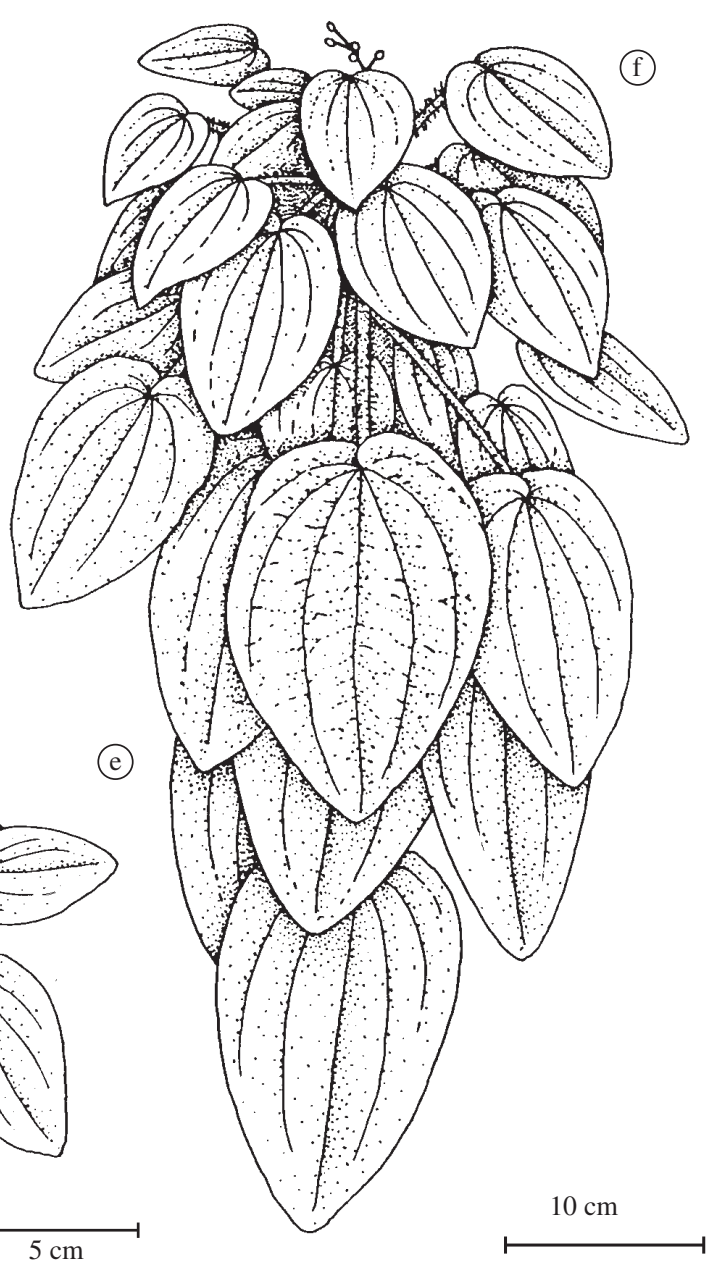

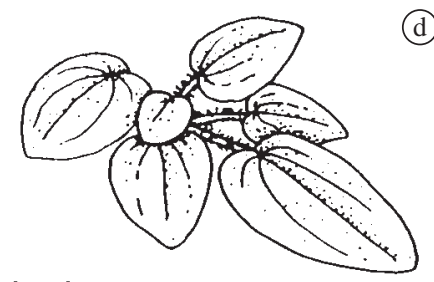

$\stackrel{\mathrm{cm}}{\longmapsto}$

(d)

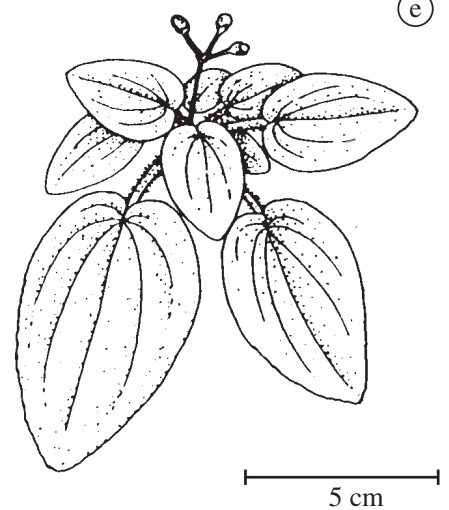


Table 1. Monthly leaf blade and petiole growth for 35 leaves that attained a limbo length $\leq 7 \mathrm{~cm}$ or $>7 \mathrm{~cm}$ in reproductive plants of Eriocnema fulva. Differences verified with the Mann-Whitney U test, Z (deviation from normal distribution), $\mathrm{n}=$ Number of measurements. $\mathrm{N}=$ number of accompanied leaves and petiole, $\mathrm{p}=$ probabilty of association being random $(<0.05), \mathrm{LG}=$ Monthly leaf blade growth, $\mathrm{PG}=$ Monthly petiole growth, $\mathrm{LET}=$ Leaf blade expansion time, $\mathrm{PET}=\mathrm{Petiole}$ expansion time.

\begin{tabular}{|c|c|c|c|c|c|c|c|c|c|}
\hline & $\begin{array}{c}\text { LG } \\
\leq 7 \mathrm{~cm} \\
(\mathbf{c m})\end{array}$ & $\begin{array}{c}\text { LG } \\
>7 \mathrm{~cm} \\
(\mathrm{~cm}) \\
\end{array}$ & $\begin{array}{c}\text { PG } \\
\leq 7 \mathrm{~cm} \\
(\mathbf{c m}) \\
\end{array}$ & $\begin{array}{c}\text { PG } \\
>7 \mathrm{~cm} \\
(\mathrm{~cm}) \\
\end{array}$ & $\begin{array}{c}\text { LET } \\
\leq 7 \mathrm{~cm} \\
\text { months }\end{array}$ & $\begin{array}{c}\text { LET } \\
>7 \mathrm{~cm} \\
\text { months }\end{array}$ & $\begin{array}{c}\text { PET } \\
\leq 7 \mathrm{~cm} \\
\text { months }\end{array}$ & $\begin{array}{c}\text { PET } \\
>7 \mathrm{~cm} \\
\text { months }\end{array}$ & $\mathbf{P}$ \\
\hline $\mathrm{N}$ & 12 & 14 & 17 & 8 & 12 & 14 & 17 & 8 & \\
\hline $\mathrm{n}$ & 81 & 211 & 132 & 118 & - & - & - & - & \\
\hline Median & 0.35 & 0.51 & 0.19 & 0.55 & 6.50 & 13.50 & 7.00 & 14.00 & \\
\hline $\begin{array}{l}\text { Confidence } \\
\text { interval }-95 \%\end{array}$ & 0.17 & 0.50 & 0.50 & 0.50 & 3 & 12 & 3 & 13 & \\
\hline $\begin{array}{l}\text { Confidence } \\
\text { interval }+95 \%\end{array}$ & 0.45 & 0.67 & 0.93 & 0.77 & 12 & 19 & 12 & 16 & \\
\hline $\mathrm{U}$ & \multicolumn{2}{|c|}{5013.00} & \multicolumn{2}{|c|}{4595.50} & \multicolumn{2}{|c|}{-} & \multicolumn{2}{|c|}{ - } & $<0.001$ \\
\hline $\mathrm{Z}$ & \multicolumn{2}{|c|}{5.46} & \multicolumn{2}{|c|}{-5.74} & \multicolumn{2}{|c|}{-} & \multicolumn{2}{|c|}{-} & $<0.001$ \\
\hline
\end{tabular}

Table 2. Parameters of linear regressions among leaf size measures. $\mathrm{N}=$ number of individuals in $15 \mathrm{~m}^{2}$; $\mathrm{a}=$ linear coefficient; $b=$ angular coefficient; $r^{2}=$ coefficient of determination, $p=$ probability of the relationship obtained being due to randomness, a common= adjusted linear coefficient for the three study years, $b$ common $=$ adjusted inclination - used to test differences between the linear coefficients between the three years. LL = Leaf blade length, PL = Petiole length, NL $=$ Number of leaves, $\mathrm{LW}=$ Leaf width, TS $=$ a posteriori Scheffé test for common $\mathrm{b}(\mathrm{p}=0,05) . \mathrm{ns}=$ Non significant. The covariance analyses and a posteriori Scheffé test only for the significant regressions LL versus $\mathrm{LW}\left(\mathrm{F}_{(2,798)}=6.32 ; \mathrm{p}<0.001\right)$ and $\mathrm{LL}$ versus PL $\left(\mathrm{F}_{(2,798)}=6.81 ; \mathrm{p}<0.001\right)$.

\begin{tabular}{|c|c|c|c|c|c|c|}
\hline & - & 1997 & 1998 & 1999 & - & TS \\
\hline & $\mathrm{N}$ & 260 & 263 & 281 & - & - \\
\hline LL & $\mathrm{a}$ & -0.0065 & 0.0349 & 0.0395 & - & - \\
\hline versus & $\mathrm{b}$ & 0.65 & 0.63 & 0.61 & - & - \\
\hline \multirow[t]{8}{*}{ LW } & $r^{2}$ & 0.95 & 0.94 & 0.95 & - & - \\
\hline & $\mathrm{p}$ & $<0.001$ & $<0.001$ & $<0.001$ & - & - \\
\hline & b common & - & - & - & 0.63 & - \\
\hline & a common & - & - & - & 0.0294 & - \\
\hline & $1997 \times 1998$ & - & - & - & - & ns \\
\hline & $1998 \times 1999$ & - & - & - & - & ns \\
\hline & $1997 \times 1999$ & - & - & - & - & $<0.05$ \\
\hline & $\mathrm{N}$ & 260 & 263 & 281 & - & - \\
\hline LL & $\mathrm{a}$ & -1.53 & -1.51 & -1.24 & - & - \\
\hline versus & $\mathrm{b}$ & 1.28 & 1.21 & 1.12 & - & - \\
\hline \multirow[t]{7}{*}{ PL } & $r^{2}$ & 0.84 & 0.84 & 0.82 & - & - \\
\hline & $\mathrm{p}$ & $<0.001$ & $<0.001$ & $<0.001$ & - & - \\
\hline & b common & - & - & - & 1.20 & - \\
\hline & a common & - & - & - & -1.40 & - \\
\hline & $1997 \times 1998$ & - & - & - & - & ns \\
\hline & $1998 \times 1999$ & - & - & - & - & ns \\
\hline & $1997 \times 1999$ & - & - & - & - & $<0.05$ \\
\hline LL & $\mathrm{a}$ & 3.95 & 4.81 & 5.58 & - & - \\
\hline versus & $\mathrm{b}$ & 0.93 & 0.99 & 0.99 & - & - \\
\hline \multirow[t]{4}{*}{ NL } & $r^{2}$ & 0.29 & 0.28 & 0.24 & - & - \\
\hline & $\mathrm{p}$ & $<0.001$ & $<0.001$ & $<0.001$ & - & - \\
\hline & b common & - & - & - & 0.97 & - \\
\hline & a common & - & - & - & 4.79 & - \\
\hline
\end{tabular}




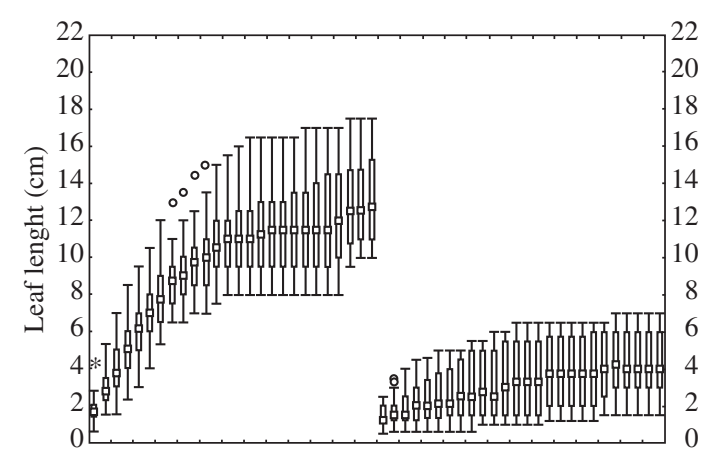

Months (26)

Figure 2. Growth of two groups of leaves from reproductive Eriocnema fulva plants during 26 months. Leaves with maximum length $>7 \mathrm{~cm}$ are represented on the left side of the graph and leaves with maximum length $\leq 7 \mathrm{~cm}$ on the right side. In each observation, the rectangle includes $50 \%$ of the individuals; the small square on the interior of the rectangle indicates the median; the horizontal lines indicate the amplitude of distribution, except for extreme values (represented by circles) and very extreme (represented by asterisks).

increased from 8.0 in 1997 and 1998 to 9.0 leaves in 1999 (Kruskal-Wallis test: $\mathrm{H}(2, \mathrm{~N}=804)=8.97$ and $\mathrm{p}<0.05)$. Therefore, the number of leaves increased in the population as a whole, but this increase was significant only after two years. In 1997 we tagged 260 plants, of which 229 remained until 1999. The median annual increase of leaves for each individual was 0.50 with confidence interval $-95 \%=0.50$ and confidence interval $+95 \%=0.50$ (the minimum increase of leaves for individual was zero and the maximum was fifteen leaves).

The relationship between length and width of the largest leaf blade was significant, showing a linear increase of length as the width increased (Table 2). Application of Scheffé test indicated that the angular coefficient (b) of this relationship was significant and differed between 1997 and 1999, thus showing a change in leaf form, which became longer in relation to its width (Table 2). The relationship between blade length and petiole length was also significant, and the angular coefficient (b) differed between 1997 and 1999, showing that the petiole tended to grow longer in relation to the leaf length (Table 2). Leaf length distribution showed that half of the individuals had small leaves, mainly vegetative plants (Figure 3a). Most individuals had a small number of leaves, especially vegetative plants (Figure 3b).

Although little variation was explained by the coefficient of determination $\left(r^{2}\right)$, the relationship between blade length and leaf number was significant (Table 2), indicating that increase in blade length and number of leaves occurred simultaneously, that is the leaves lasted long and continued to grow over time, while new leaves were added. Covariance analysis of the slopes of the regression lines of blade length versus leaf number between the two years (Table 2) was not significant $\left(\mathrm{F}_{(2798)}=0.12 ; \mathrm{p}=0.88\right)$, indicating that the increase in
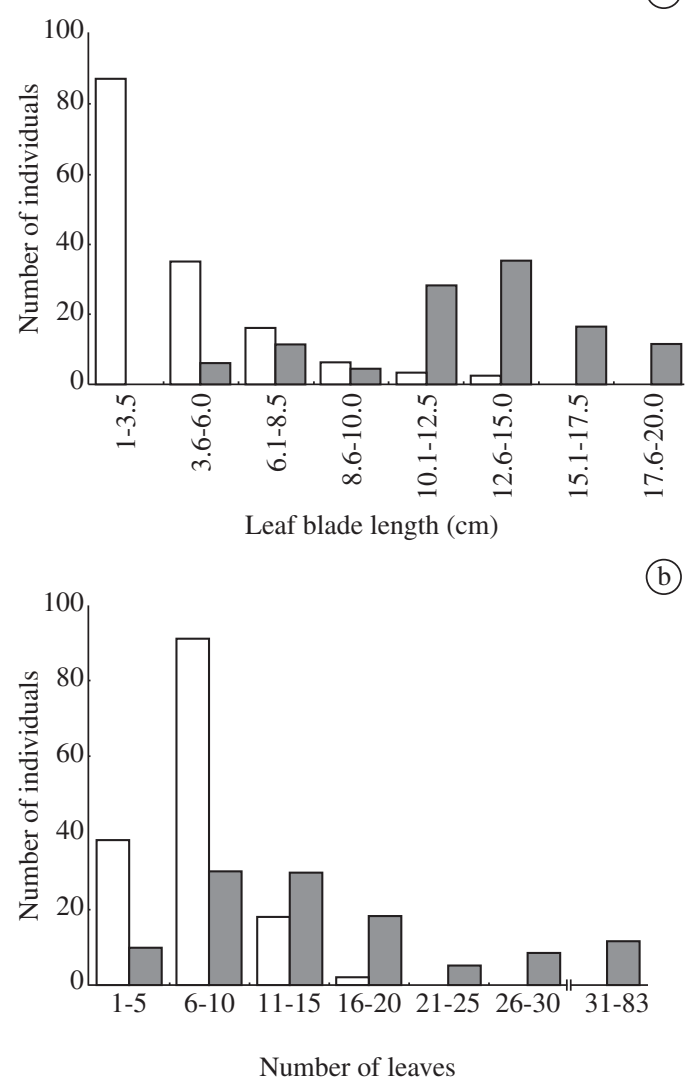

Figure 3. a) Distribution of the leaf lamina length and b) number of leaves of 260 individuals of Eriocnema fulva recorded in October/1997. White bars = vegetative individuals. Gray bars = reproductive individuals.

blade length and leaf number occurred at the same rate in the years sampled.

The relationships between the size variables were significant, with high values of the coefficient of determination $\left(r^{2}\right)$ for most regressions (Table 2). In conjunction, the regression parameters and their alteration among years, as well as the diagrams (Figure 3), show how plant size increased as the plant developed towards the reproductive phase. Both length and width of the blade increased during ontogeny, but length tended to increase faster (Table 2). As the blade length increased, so did the petiole length, placing the leaf lamina farther away from the stem. The relationship between lamina length and petiole length was better fitted in a non-linear model $\left(\mathrm{N}=260\right.$, year 1997, $\mathrm{PL}=0.467 \mathrm{LL}^{1.34} \mathrm{r}^{2}=0.90$; $\mathrm{p}<0.001$ ), in which the petiole length continued to increase while blade length tended to stabilize or grow at a smaller rate. The number of leaves (Figure $3 b$ ) and the blade length (Figure 3a) increased as the stem length increased, and the larger the number of leaves on the plant the larger the length of the blade and petiole. The relationship between blade length and stem length proved to be very important, because the number of reproductive individuals was much greater in the presence 
of stem associated to blade length greater than $10 \mathrm{~cm}$. The relation between number of leaves and stem length was significant (linear regression, $\mathrm{N}=260$, year 1997 , $\left.\mathrm{r}^{2}=0.55 ; \mathrm{a}=6.80 ; \mathrm{b}=1.80 ; \mathrm{p}<0.001\right)$. A non-linear model adjusted better to the relationship between stem length and leaf length $(\mathrm{N}=260$, year $1997, \mathrm{LL}=6.449$ $\left.\mathrm{SL}^{0.397}, \mathrm{r}^{2}=0.66 ; \mathrm{p}<0.001\right)$, indicating that the stem continued to grow while blade length stabilized or grew at a smaller rate after reaching a certain size.

The correlation between the number of leaves in 1997 and in 1999 was positive (Pearson coefficient $\mathrm{r}=0.88 ; \mathrm{p}<0.05 ; \mathrm{N}=226$ ). It meant that the individuals with larger number of leaves had greater increase in the number of leaves when compared to plants with smaller number of leaves. By using a non-linear model with data from a two-year period (1997-98) we projected the increase of leaf number in an average plant as 81 leaves in 2033. The projection began with two leaves in 1997 because this was the smallest number of leaves found in a plant with the largest blade length $\geq 1 \mathrm{~cm}$, and was interrupted at 81 leaves in 2033 because the largest plant found in the population had 83 leaves (Figure 3b).

\section{Discussion}

\subsection{Leaf growth and survival}

Success in protecting plant species threatened with extinction depends on, among other variables, knowledge regarding the species life history and the dynamics of its population (Schemske et al., 1994). For Eriocnema fulva the leaf is a fundamental component to understand the population life history. A few hypotheses attempt to explain the adaptive significance of leaf lifespan. These hypotheses were developed in specific environmental contexts in order to explain the existence of deciduous and evergreen plants (Chabot and Hicks, 1982). The patterns of leaf production in evergreen species vary from an almost continuous flux in pioneer species to a discontinuous flux in many non-pioneer species of tropical forests (Coley, 1983). Leaf flux in the reproductive individuals of E. fulva was continuous in the sense that they emerged one at a time, although this pattern would have to be confirmed by long-term monitoring. Our results on leaf expansion of E. fulva showed that, such as in other understory species, development is slow when compared to leaves of canopy tree species of tropical forests (Williams-Linera, 2000). In general, species from tropical forest understory tend to have longer leaf lifespan than those of the canopy (Parkhust and Loucks, 1972; Reich et al., 1992). The average time interval necessary for the full leaf expansion of E. fulva was greater than 13 months. Considering that the duration of leaf expansion is positively correlated with leaf lifespan (Diemer, 1998), the leaf of E. fulva would live longer than two years, in order to compensate construction costs (Kikuzawa, 1995). Leaves of tree and shrub species of tropical forest understory have a lifespan of 1 to 5 years (Bentley, 1979; Mulkey et al., 1991; Coley et al., 1993;
Freiberg and Freiberg, 1999; Kursar and Coley, 1999). The leaf expansion period of E. fulva was relatively long, and considering that after 26 months $28 \%$ of the surviving leaves were still growing, we estimate a leaf lifespan longer than 3 years. Significant alterations in leaf size were detected only after two years, although it was not possible to detect any changes in stem length during this period. These results agree with the hypothesis that longer leaf lifespans are to be found in slow growing plants (Crawley, 1997; Reich et al., 1992). Small leaves (blade length up to $7 \mathrm{~cm}$ ) died in a greater proportion than large leaves, and this fact poses a few questions: Is size as important for leaf survival as it is for individual survival? Or would larger leaves live longer just to compensate for their construction costs? It would be interesting to investigate whether in the same individual leaves of different size would have distinct lifespans: would small leaves have shorter lifespans?

The size of E. fulva leaves is large in relation to the stem size, and as the number of leaves increases so does the length of all leaves and the plant as a whole. Thus, E. fulva leaves contribute to the increase of the overall plant size, and probably influence plant survival (Andrade, 2004), but growth is slow, two years being necessary to observe significant alterations in the shape and size of the plants in the population studied. Eriocnema fulva has a positive relationship between fertility and size (Andrade, 2004). We suspect that the increase in leaf size and number is also related to the plant fitness, since larger plants generally have greater fecundity (Solbrig, 1981; Silvertown and Lovett Doust, 1993; Begon et al., 1996).

Thomas and Stoddart (apud Chabot and Hicks, 1982) argued that physiological ageing and leaf lifespan seem to be part of a general adaptive strategy of plants. Eriocnema fulva is an understory species, and light is a limiting factor for understory species in general (Pearcy, 1983; Chazdon and Fetcher, 1984). Therefore, large-sized and longer lasting leaves are adaptations that contribute to individual survival. Or better, leaf size and longevity compensate for the greater construction costs in light-limited environment, according to the hypothesis that natural selection favors leaves with the longest lifespan in limiting habitats (Chabot and Hicks, 1982; Reich et al., 1992; Kikuzawa, 1995).

\subsection{Leaf growth and its relationship to plant structure}

Plants of tropical forests have morphological variation in leaf and crown architecture (Tuner et al. 2000, Valladares, et al., 2002). For example, in species of Arecaceae the stem represents the largest part of the plant. Dicotyledons of forest canopy also have the largest vertical size proportion represented by their trunk, and the leaves are small when compared to the size of the individual as a whole. In tropical understory species, morphological variation related to the efficient absorption of light is great, encompassing species with different patterns of phyllotaxy, leaf sizes, types of crown, and plant architecture (Valladares, et al. 2002). In E. fulva, the largest stem length was $36 \mathrm{~cm}$ and the largest leaf blade length 
was $17 \mathrm{~cm}$ in a total of 83 leaves. Comparatively, if this plant were a tree with a trunk $30 \mathrm{~m}$ in height, it would still have 83 leaves, but the largest leaf would measure $14 \mathrm{~m}$ in length, assuming that both stem and leaf length would increase linearly at the same rate. The leaf and it characteristics, such as lifespan, size and resistance, contribute directly to the survival of E. fulva individuals (Andrade, 2004). The stem seems to be important as well, although it grows slowly and most individuals in the population did not have a measurable stem. The statistical significance of all the relations among size measures in E. fulva indicates that the leaf is a component of great importance for the overall size of the plant, especially when we consider it together with the length of the stem and petiole, which seem to be the major determinants of plant architecture.

Therefore, if size and number of leaves are directly related to the size of an E. fulva individual, they can be used to indicate the plant age. Hanzawa and Kalisz (1993) observed that the total leaf area, rhizome volume and plant age were positively correlated in Trillium grandiflorum (Michx.) Salisb (Liliaceae). In E. fulva the flux of new leaves is continuous and large leaves (largest leaf blade length greater than $7 \mathrm{~cm}$ ) took an average of 6.5 months to fully expand. Therefore, we may speculate that an adult with 30 leaves would be at least 195 months or 16.25 years old. Considering the projection for leaf number increase, we could calculate the number of years necessary for an average plant to get 81 leaves as 36 years. However, the model we used to carry out such an estimate considers the number of leaves found in the previous observation period and does not take into account the death rate of leaves. Hence, the plant may be much older than our estimate. In order to devise the best method to estimate plant age, it is necessary to monitor leaf dynamics in different size classes. The leaf lifespan we estimated is in the range of estimated lifespans for perennial herbaceous plants, which average 28.3 years for 40 species based on studies on demographic structure (Ehrlén and Lehtilá 2002). Our estimate is preliminary, and further studies on leaf and population dynamics of E. fulva are necessary. The median annual increase of 0.5 leaf per individual is smaller than the average of 3.17 leaves per individual in other tropical understory species (Bentley 1979), and possibly E. fulva develops slowly when compared to other understory species in tropical forests. The few studies on tropical understory herbaceous plants (Mulkey et al., 1991; Sharpe, 1993; Horvitz and Schemske, 1995; Bruna and Kress, 2002) do not emphasize the development and lifespan of leaves.

Generally, leaves in the forest canopy are vertically oriented and those found in the understory are horizontally oriented, thereby maximizing the interception of light under the limitation imposed by their location (Crawley, 1997). Eriocnema fulva occurs in a special habitat in the understory, growing on rocky walls along the edge of streams. Its leaves optimize the exploration of space by having different sizes and by differential lengthening of the petiole. The changes of petiole growth in the popula- tion as a whole, detected after two years, indicated slow alterations in the architecture of the plant in search for light, as described for species of Arecaceae (Kahn, 1986; Carvalho et al., 1999). In these monocotyledons, after blade full expansion the energetic investment is directed towards the positioning of the leaf by the petiole, thus optimizing light interception for photosynthesis (Kahn, 1986; Carvalho et al., 1999). In E. fulva petiole growth is possibly the best way to explore a heterogeneously illuminated understory environment, and leaf positioning could be critical to plant growth and survival.

Acknowledgments - We are grateful to the National Council of Scientific and Technologic Development (CNPq) for a scholarship awarded to the first author. We thank the Instituto Estadual de Florestas (IEF) for logistical help with the research and Minerações Brasileiras Reunidas for permission to work in the reserve.

\section{References}

AIDE, TM., 1993. Patterns of leaf development and herbivory in a tropical understorey community. Ecology vol. 74 no. 3, p. $455-466$.

ALVES, WA., 1988. Carta do meio ambiente e sua dinâmica da microbacia do córrego do Cardoso, Nova Lima, MG. (Monografia) - Instituto de Geociências, UFMG, Belo Horizonte, Minas Gerais.

ANDRADE, PM., 1993. Estrutura do estrato herbáceo de trechos da Reserva Biológica Mata do Jambreiro, Nova Lima,MG. (Tese de Mestrado) - Instituto de Biologia, UNICAMP, Campinas, São Paulo.

ANDRADE, PM., 2004. Biologia de uma população de Eriocnema fulva Naudin (Melastomataceae). (Tese de Doutorado) - Instituto de Biologia, UNICAMP, Campinas. São Paulo.

BADINI, J., 1940. Contribuição a geobotânica das Melastomaceas Ouropretanas. Revista Farmaceutica de Ouro Preto. ano 1 no. 4/5, p. 8. separata.

BECKER, P., STUART, JD., MOKSIN, M., HJ-ISMAIL, MZ., and SIMANJUNTAK, P M. 1999. Leaf size distributions of understorey plants in mixed dipterocarp and heath forests of Brunei. Journal of Tropical Ecology, vol. 15, no. 1, p. $123-128$.

BEGON, M., HARPER, JL. and TOWNSED, CR. 1996. Ecology: individuals, populations and communities. $3^{\text {rd }}$ ed. Blackwell Science, Oxford.

BENTLEY, BL., 1979. Longevity of individual leaves in a tropical rainforest understory. Annals of Botany, vol. 43, no. 1, p. $119-121$.

BRUNA, EM. and KRESS, WJ., 2002. Habitat fragmentation and the demographic structure of an Amazonian understory herb (Heliconia acuminata). Conservation Biology, vol. 16, no. 5, p. 1256-1266.

CARVALHO, RM., MARTINS, FR., and Santos, FAM., 1999. Leaf ecology of pre-reproductive ontogenetic stages of the palm tree Euterpe edulis Mart. (Arecaceae). Annals of Botany, vol. 83 , no. 3, p. 225-233. 
CAVELIER, J., MACHADO, J. L., VALENCIA, D., MONTOYA, J., LAIGNELET, A., HURTADO, A., VARELA, A. and MEIJA, C., 1992. Leaf demography and growth rates of Espeletia barclayana Cuatrec. (Compositae), a caulescent rosette in a Colombian Paramo. Biotropica, vol. 24, no. 1, p. 52-63.

CETEC. FUNDAÇÃO CENTRO TECNOLÓGICO DE MINAS GERAIS, 1983. Mapa 3/ Solos. Diagnóstico ambiental do estado Minas Gerais. Fundação Centro Tecnológico de Minas Gerais, Comissão de Política Ambiental, Belo Horizonte, Minas Gerais.

CHABOT, BF. and HICKS, DJ., 1982. The ecology of leaf life spans. Annual Review of Ecology and Systematics, vol.13, p. 229-259.

CHAZDON, RL. and FETCHER, N., 1984. Photosynthetic light environments in a lowland tropical forest in Costa Rica. Journal of Ecology, vol. 72, no. 2, p. 553-564.

CLARK, DB., CLARK, DA. and GRAYUM, MH., 1992. Leaf demography of a neotropical rain forest cycad, Zamia skinneri (Zamiaceae). American Journal of Botany, vol. 79, no. 1 , p. 28-33.

COGNIAUX, A. 1883. Melastomataceae Tribus I Microlicieae Triana. In MARTIUS, CFP., ENDLICHER, S., EICHLER, AG. AND URBAN, J.(ed.) 1840/1906. Flora brasiliensis:enumerativo plantarum in Brasilia. vol. 14, tomo 3. Editora Lipsiae apud Frid. Fleischer in comm. Cidade Monachii.

COLEY, PD., 1983. Herbivory and defensive characteristics of tree species in a lowland tropical forest. Ecological Monographs. vol. 53, no. 2, p. 209-233.

COLEY, PD., KURSAR, TA. and MACHADO, JL., 1993. Colonization of tropical rain forest leaves by epiphylls: effects of site and host plant leaf lifetime. Ecology, vol. 74, no. 2, p. 619-623.

COPAM - CONSELHO ESTADUAL DE POLITICA AMBIENTAL., 1997. Deliberação COPAM No 85. Aprova lista das espécies ameaçadas de extinção da flora do Estado de Minas Gerais. Belo Horizonte, Minas Gerais.

COSTA, CSB. and SEELIGER, U., 1988a. Demografia de folhas de Spartina ciliata Brong. em dunas e brejos costeiros. Revista Brasileira de Botânica, vol. 11, no. 1-2, p. 85-94.

-, 1988b. Demografia de folhas de Hydrocotyle bonariensis Lam., uma planta rizomatoza perene nas dunas costeiras do Rio Grande do Sul, Brasil. Revista Brasileira de Biologia, vol. 48, no. 3, p. 443-451.

COSTA, CSB., SEELIGER, U. and CORDAZZO, CV., 1991. Leaf demography and decline of Panicum racemosum populations in coastal foredunes of southern Brasil. Canadian Journal of Botany, vol. 69, no. 7, p. 593-1599.

CRAWLEY, MJ., 1997. Life history and environment. In CRAWLEY, MJ. (ed.) Plant ecology, $2^{\text {nd }}$ ed. Blackwell Scientific, Oxford, p. 73-131.

DIEMER, M., 1998. Life span and dynamics of leaves of herbaceous perennials in high-elevation environments: 'news from the elephant's leg'. Functional Ecology, vol. 12 no. 3, p. 413-425.

DOLPH, GE. and DILCHER, DL., 1980. Variation in leaf size with respect to climate in Costa Rica. Biotropica, vol. 12, no. 2, p. 91-99.
EHRLÉN, J. and LEHTILÄ, K., 2002. How perennial are perennial plants? Oikos. vol. 98, no. 2, p. 308-322.

ESCUDERO, A. and DEL ARCO, JM., 1987. Ecological significance of the phenology of leaf abscissiono. Oikos, vol. 49 , no. 1 , p. $11-14$.

FREIBERG, L. and FREIBERG, M., 1999. Foliage growth rhythm and longevity of tree layer in the A-Brenes Biological Reserve, Costa Rica. Revista de Biología Tropical, vol. 47, no. 3, p. 339-349.

GIVNISH, TJ., 1984. Leaf and canopy adaptations in tropical forests. In MEDINA, EH., MOONEY, A., VÁSQUES-YANES, C., eds. Physiological ecology of plants of the wet tropics. Dr. W. Junk publishers, New York, p. 51-84.

HANZAWA, FM. and KALISZ, S., 1993. The relationship between age, size, and reproduction in Trillium grandiflorum (Liliaceae). American Journal of Botany. vol. 80, no. 4, p. $405-410$.

HARPER, JL., 1989. The value of a leaf. Oecologia, vol. 80, no. 1 , p. 53-58.

HEGARTY, EE., 1990. Leaf life - span and leafing phenology of lianas and associated trees during rainforest successiono. Journal of Ecology, vol. 78, no. 2, p. 300-312.

HORVITZ, CC. and SCHEMSKE, DW., 1995. Spatiotemporal variation in demographic transitions of a tropical understory herb: projection matrix analysis. Ecological Monographs, vol. 65 , no. 2, p. 155-192.

JURIK, TW. and CHABOT, BF., 1986. Leaf dynamics and profitability in wild strawberries. Oecologia, vol. 69, no. 3, p. 296-304.

KAHN, F., 1986. Life forms of Amazonian palms in relation to forest structure and dynamics. Biotropica, vol. 18, no. 3, p. 214-218.

KIKUZAWA, K. 1995. The basis for variation in leaf longevity of plants. Vegetatio, vol. 121, p. 89-100.

KITAJIMA, K., MULKEY, SS. AND WRIGHT, SJ. 1997. Decline of photosynthetic capacity with leaf age in relation to leaf longevity for five tropical canopy tree species. American Journal of Botany, vol. 84, no. 5, p. 702-708.

KOHYAMA, T. 1987. Significance of architecture and allometry in saplings. Functional Ecology, vol. 1, no. 4, p. 399-404.

KOHYAMA, T. and HOTTA, M., 1990. Significance of allometry in tropical saplings. Functional Ecology, vol. 4, no. 4, p. 515-521.

KURSAR, TA. and COLEY, PD., 1999. Contrasting modes of light acclimation in two species of the rainforest understory. Oecologia, vol. 121, no. 4, p. 489-498.

LOWMAN, MD., 1992. Leaf growth dynamics and herbivory in five species of Australian rain-forest canopy trees. Journal of Ecology, vol. 80, no. 3, p. 433-447.

MULKEY, SS., SMITH, AP. and WRIGHT, SJ., 1991. Comparative life history and physiology of two understory neotropical herbs. Oecologia, vol. 88, no. 2, p. 263-273.

MULKEY, SS., WRIGHT, SJ. and SMITH, AP. 1993. Comparative physiology and demography of three Neotropical forest shrubs: alternative shade-adaptive character syndromes. Oecologia vol. 96, no. 4, p. 526-536. 
PARKHUST, DF. and LOUCKS, OL., 1972. Optimal life size in relation to environment. Journal of Ecology, vol. 60, no. 2, p. 505-537.

PEARCY, RW., 1983. The light environment and growth of $\mathrm{C} 3$ and $\mathrm{C} 4$ tree species in the understory of a Hawaiian forest. Oecologia, vol. 58, no. 1, p. 19-25.

PLAMBEL., 1977. Carta de Belo Horizonte. Escala 1:25.000. RMBH 20/32 Folha SE 23-ZC-VI-3-SO Superintendência da Região Metropolitana de Belo Horizonte. In Planejamento Região Urbana de Belo Horizonte. Convênio PLAMBEL/SECT COPASA/ CETEL/ CEMIG, Belo Horizonte, Minas Gerais.

REICH, PB., UHL, C., WALTERS, MB. and ELLSWORTH, DC., 1991. Leaf life- span as a determinant of the leaf structure and function among 23 Amazonian tree species. Oecologia, vol. 86 , no. 1 , p. 16-24.

REICH, PB., WALTERS, MB., and ELLSWORTH, DC., 1992. Leaf life-span in the relation to leaf, plant and stand characteristics among diverse ecosystems. Ecological Monographs, vol. 62, no. 3: 365-392.

RICHARDS, PW., 1976. The tropical rain forest: an ecological study. Cambridge University Press, Cambridge.

SANTOS, FAM., 2000. Growth and leaf demography of two Cecropia species. Revista Brasileira de Botânica, vol. 23, no. 2, p. 133-141.

SCHEMSKE, DW., HUSBAND, BC., RUCKELSHAUS, MH., GOODWILLIE, C., PARKER, I. M. and BISHOP, JG., 1994. Evaluating approaches to the conservation of rare and endangered plants. Ecology, vol. 75, no. 3, p. 584-606.

SHARPE, JM. 1993. Plant growth and demography of the Neotropical herbaceous fern Danea wendlandii (Marattiaceae) in a Costa Rica rain forest. Biotropica, vol. 25, no. 1, p. 85-94.
SILVERTOWN, JW. and LOVETT DOUST, J., 1993. Introduction to plant population ecology. $3^{\text {rd }}$ edno. Blackwell, Cambridge.

SOKAL, RR. and ROLHF, JF., 1969. Biometry. W.H.Freeman and Company, San Francisco.

SOLBRIG, OT., 1981. Studies on the population biology of the genus Viola. II. The effects of plant size on fitness in Viola sororia. Evolution, vol. 35, no. 61080-1093.

STERK, FJ. and BONGERS, F., 1998. Ontogenetic changes in size, allometry and mechanical design of tropical rain forest trees. American Journal of Botany, vol. 85, no. 2, p. 266-272.

TELENIUS, A., 1993. The demography of the short-lived perennial halophyte Spergularia maritima in a sea-shore meadow in south-western Swedeno. Journal of Ecology, vol. 81, no. 1, p. 61-73.

TUNER, IM., LUCAS, PW., BECKER, P., WONG, SC., YONG, J. HW. CHOONG, MF. and TYREE, MT., 2000. Tree leaf form in Brunei: a heath forest and a mixed dipterocarp forest compared. Biotropica, vol. 32, no. 1, p. 53-61.

VALLADARES, F., SKILLMAN, JB. and PEARCY, RW. 2002. Convergence in light capture efficiencies among tropical forest understory plants with contrasting crow architectures: a case of morphological compensationo. American Journal of Botany, vol. 89 no. 8 , p. $1275-1284$.

WALKER, LR. and APLET, GH. 1994. Growth and fertilization responses of Hawaiian tree ferns. Biotropica, vol. 26, no. 4, p. $378-383$.

WILLIAMS-LINERA, G., 2000. Leaf demography and leaf traits of temperate deciduous and tropical evergreen broadleaved trees in a Mexican montane cloud forest. Plant Ecology., vol. 149 , no. 2 , p. $233-244$.

ZAR, H. 1984. Biostatistical analysis. $2^{\text {nd }}$ edn Prentice-Hall International Editions, Londono. 